\title{
Congratulations to The Canadian Entomologist on this, its sesquicentennial anniversary!
}

\author{
Kevin D. Floate, ${ }^{1}$ Dezene Huber
}

\begin{abstract}
"For a long time, the wielders of the butterfly net and beetle bottle in Canada have been longing for some medium of intercommunication-some mode of telling one another what they have taken, how and where they have taken it, and what they are in want of. This desire the Entomological Society purpose now to satisfy to some extent by the publication of the Canadian Entomologist... we hope and believe, too confidently, perhaps, it may be - that it will by and by grow and increase, and acquire goodly dimensions, and become a handsome and valuable exponent of the progress of the Entomological Science in this Dominion...” (Bethune 1868)
\end{abstract}

These were the words from Charles James Stewart Bethune, the Editor-in-Chief, in the opening pages of the first issue of The Canadian Entomologist (TCE), published in August of 1868. How pleased he would be to learn that on the 150th anniversary of the founding of the journal, it continues to flourish and now serves a global audience. Initially having a mainly regional focus, TCE is now the official journal of the Entomological Society of Canada and has undergone a series of changes throughout its long history - both in scope and extent. The intent of this editorial is to capture the flavour of these changes, by providing a historical retrospective of the first 150 years of the journal with an eye towards guiding its continued success into the future.

Upon beginning our research, we were amazed to learn that the journal has had only 21 Editorsin-Chief (Table 1). Current Editor-in-Chief, Dezene Huber, is the 22nd. Most noteworthy among them is perhaps Bethune, a co-founder of the Entomological Society of Canada who served two terms as Editor-in-Chief for a total of 28 years (Lyman 1910). The editorial board increased from one member (Bethune for volumes 1-3) to four members (volumes 4-17), to 10 members starting with volume 49. However, archived copies of the journal seem to identify only two editorial board members for volumes 42-48; i.e., E.M. Walker as
Editor and Bethune as Emeritus Editor. The only woman to serve as the Editor-in-Chief, M.R. Mackay, was also the first female graduate in Entomology from the University of Saskatchewan. The current editorial board includes an Editorin-Chief, an Assistant Editor, and about two dozen subject editors. The average term for the first six Editor-in-Chiefs was 15 years (1868-1958). Subsequent terms have averaged four years. This reduction can perhaps be attributed to increasing demands of the position.

These demands are partially captured with changes in the number of pages and items published in the journal over time (Fig. 1). For the purpose of this editorial, we defined an item as a document in TCE archives (www.cambridge.org/core/journals/ canadian-entomologist/all-issues) with a unique digital object identifier code. These items include advertisements, announcements, book reviews, correspondence, editorials, minutes of meetings, obituaries, requests, and scientific articles.

The first volume (12 issues) contained a total of 110 pages reporting on 70 items. Following a period of relative stability, the numbers of items published per year started to decline around 1910 and reached a nadir during World War II. Wartime conditions reduced the number of submitted manuscripts and severely delayed delivery of the journal to subscribers (Thompson 1948). Starting

Received 16 November 2017. Accepted 23 November 2017. First published online 11 January 2018.

K.D. Floate, ${ }^{1}$ Lethbridge Research and Development Centre, Agriculture and Agri-Food Canada, Lethbridge, Alberta, T1J 4B1, Canada

D. Huber, Natural Resources and Environmental Studies Institute, University of Northern British Columbia, Prince George, British Columbia, V2N 4Z9, Canada

${ }^{1}$ Corresponding author (e-mail: Kevin.Floate@agr.gc.ca).

Subject editor: Andrew Smith

doi:10.4039/tce.2017.64 
Table 1. List of Editors-in-Chief for The Canadian Entomologist since its founding in 1868.

\begin{tabular}{|c|c|c|c|}
\hline Editor-in-Chief & Term in office & Years of service & Biography \\
\hline Bethune, Charles J.S. & $\begin{array}{l}1868-1873 \\
1887-1909\end{array}$ & 28 & $\begin{array}{l}\text { Lyman (1910), Gillott (2013a), www.thecanadianencyclopedia.ca/ } \\
\text { en/article/charles-bethune }\end{array}$ \\
\hline Saunders, William & $1874-1886$ & 13 & $\begin{array}{l}\text { Bethune (1886), Gillott (2013b), www.biographi.ca/en/bio/ } \\
\text { saunders_william_14E.html }\end{array}$ \\
\hline Walker, Edmund M. & $1910-1920$ & 11 & Gibson (1921), https://archive.org/details/centennialofento00wigg \\
\hline McDunnough, James H. & $1921-1938$ & 18 & $\begin{array}{l}\text { Freeman (1962), http://images.peabody.yale.edu/lepsoc/jls/1960s/ } \\
\text { 1962/1962-16(4)209-Ferguson.pdf }\end{array}$ \\
\hline Brown, Williamson J. & 1939-1946 & 8 & Becker (1977) \\
\hline Thompson, William R. & $1947-1958$ & 12 & Ross (1959), Chant (1967) \\
\hline Munroe, Eugene & $1959-1960$ & 2 & Anonymous $(1982,1987)$, Solis $(2008)$ \\
\hline Mason, William R.M. & $1961-1963$ & 3 & Sharkey (1992) \\
\hline Mackay, Margaret R. & $1964-1965$ & 2 & $\begin{array}{l}\text { Anonymous (1975), https://stbarbebaker.wordpress.com/2017/03/ } \\
\text { 09/margaret-rae-mckay }\end{array}$ \\
\hline Pielou, D. Patrick & $1966-1973$ & 8 & Anonymous (1973), Becker (2001) \\
\hline Vickery, Vernon R. & $1974-1975$ & 1 & Anonymous (1974, 1988), Arntfield (2011) \\
\hline Morrison, Paul E. & $1975-1978$ & 4 & Becker (2004) \\
\hline Eidt, Doug & $1979-1983$ & 5 & Sweeney et al. (2011) \\
\hline Smith, Stephen M. & 1984-1985 & 2 & $\begin{array}{l}\text { Morris (1984), https://uwaterloo.ca/centre-for-teaching-excellence/ } \\
\text { stephen-smith-recipient-distinguished-teacher-award-1980 }\end{array}$ \\
\hline Ewen, Alwyn B. & $1986-1993$ & 8 & Gillott (2008) \\
\hline Kevan, P. & 1994-1997 & 4 & Anonymous $(1993,2005)$ \\
\hline Turgeon, Jean & $1998-2003$ & 6 & \\
\hline Ring, Richard A. & 2004-2006 & 3 & Anonymous (2006b), Ring (2007) \\
\hline Bennett, Robb & $2007-2011$ & 5 & Anonymous (2012) \\
\hline Buddle, Chris M. & 2012-2014 & 3 & Anonymous (2006a, 2006c) \\
\hline Floate, Kevin D. & $2015-2017$ & 3 & Anonymous (2001) \\
\hline Huber, Dezene & $2018-$ & & Anonymous (2010) \\
\hline
\end{tabular}

Note: Sources of biographical information are provided where known.

in about 1949, numbers of both pages and items annually published increased sharply to reach a maximum of 1999 pages and 230 items in 1972 (volume 104). The length of articles also has increased over time (Fig. 2). Initially, and until about 1947, articles averaged three to five pages in length. The decade from 1948 to 1957 saw a sudden jump to seven pages per article, with articles in the following three decades averaging eight pages in length. From 1988 to 1997, articles have averaged close to 12 pages and have remained steady at that level ever since. The longest article published by the journal thus far is 117 pages (Erwin 1994). We attribute the increased number of submissions between 1950 and the mid-1970s at least partially to an increase in the number of entomologists hired by the federal government and universities. Declines in the Canadian economy in 1970, the early 1980s, and from 1990 onwards led to a decline in these positions (Danks 1994) and presumably contributed to the corresponding decline in journal submissions (Fig. 1). This trend reversed in 2009 with the number of total pages and items published in TCE reaching 1107 pages and 100 items in 2016.

It quickly became apparent to us that the nature of these items has changed with time. To visually encapsulate these changes and stimulate exploration of the archive of the journal, we generated four word clouds corresponding to four, five-year, time periods evenly spaced across the history of the journal; i.e., 1868-1873 (volumes 1-5), 19191923 (volumes 51-55), 1969-1973 (volumes 101-105), and 2012-2016 (volumes 144-148) (Fig. 1). We first made text files of the titles of items in the TCE archive for each time period. We then copied the contents of the text file into an online word cloud software programme (www. wordclouds.com) to generate a word list that quantified the number of times each word appeared in the text file. The programme subsequently assigned each word a font size based on the frequency of its occurrence and arranged the words in a word cloud. Common words assigned a very large font size may be excluded from the 
Fig. 1. Yearly number of pages (upper line) and items (lower line) published in The Canadian Entomologist. Values were obtained from TCE archives via the website of the journal (www.cambridge.org/core/journals/ canadian-entomologist). Four time periods identified by the vertical grey bars were singled out for detailed examination of journal content (see text).

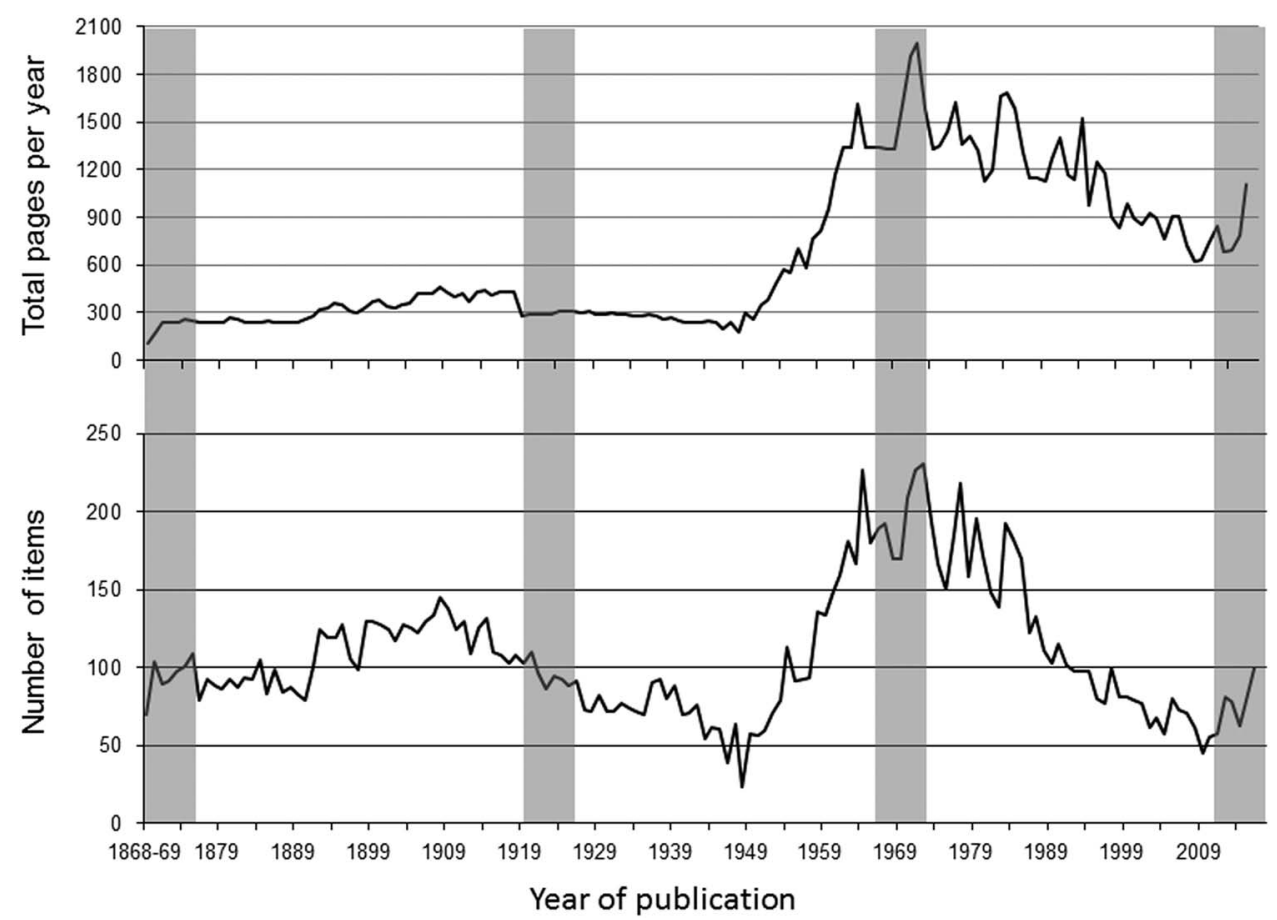

Fig. 2. Number of pages per item, averaged per decade.

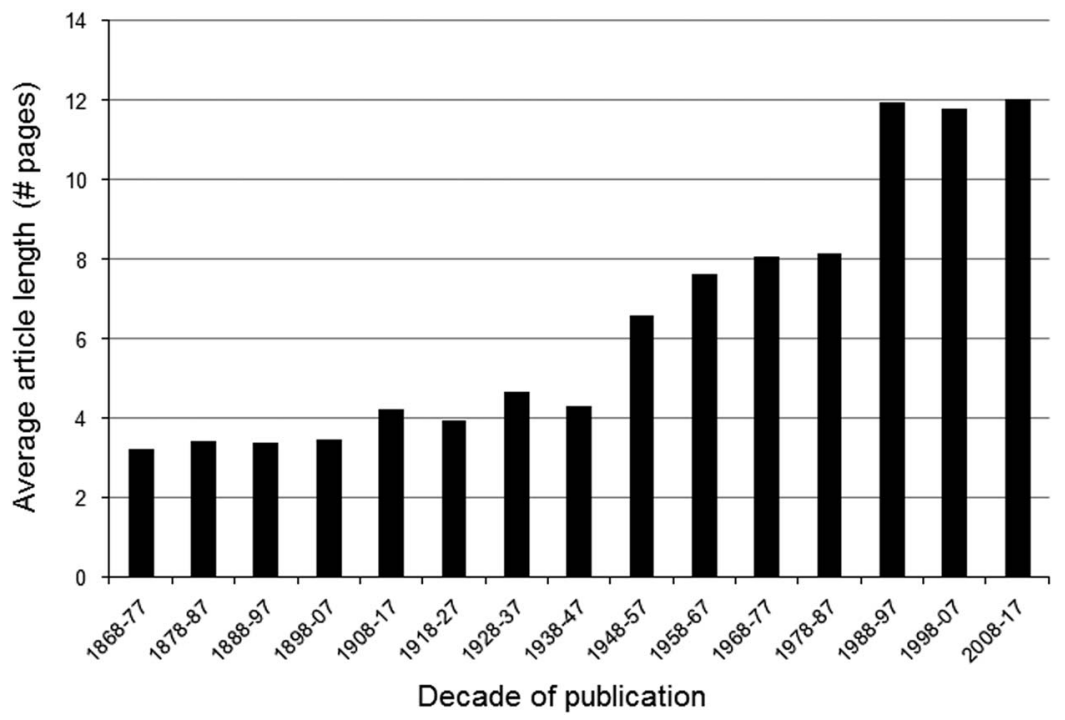


word cloud due to space limitations. Conversely, uncommon words may be assigned a font size that is too small to clearly read. To address these limitations, we modified text files and word lists before generating the word clouds (Supplementary Appendix S1). The main modification was the removal of insect order names. Thus, by removing "Diptera" from word lists, we created space in the word cloud to include related and more informative terms such as "Cecidomyiidae". However, to ensure that common words excluded from word clouds were not overlooked, we list the 50 most common words for each time period in Table 2.

Examination of the resulting word clouds conveys an increasing sense of complexity and volume in journal content (Fig. 3). The looser structure of the word cloud for years $1868-1873$ is generated from a word list of 344 terms, each averaging 3.0 repetitions (Table 2). In subsequent time periods, the number of words and their average occurrence change as follows: 19191923 (2583 words, average of 2.7 times), 19691973 (8091 words, average of 3.2 times), and 2012-2016 (3979 words, average of 2.2 times). Given that the total number of items in the first two time periods ( $n=346$ and 488 , respectively) and in the final time period $(n=337)$ is roughly the same, the more intricate nature of the final time period denotes the use of more words per title and less repetition of those words across titles.

The occurrence of terms including "notes", "miscellaneous", "advertisements", "descriptions", and "books" in the first two time periods (1868-1873, 1919-1923) reflects the dual role of the journal during those periods as both a newsletter and as a venue for scientific reports. Many of these words appear in specific sections of each issue; e.g., "book reviews", "miscellaneous notes". Other words reflect reports of annual meetings for branches of the Entomological Society of Canada in London and Kingston, Ontario. The occurrence of "British" during the period $1868-1873$ is mainly in the context of the re-occurring phrase "Insects of the northern parts of British America", a reminder that Canadian Confederation occurred in 1867 and, at that time, only included Ontario, Québec, Nova Scotia, and New Brunswick. British Columbia joined Canada in 1871, such that the occurrence of "British" during the period 1919-1923 is primarily in reference to reports from that province. Items of "correspondence" provide further reminders of historical events. One such item is a plea for specimens from a researcher who lost their entire collection of insects in the Great Chicago Fire (Anonymous 1871). Another item is an appeal for funds to support the continued survival in Vienna, Austria, of a scientific society left destitute by the ravages of World War I (Anonymous 1922). The Canadian Entomologist is now strictly a scientific journal with correspondence-type items appearing in the Bulletin of the Entomological Society of Canada, which began publication in 1969 (http:// esc-sec.ca/wp/publications/bulletin).

The frequency of words in the titles of items across the four time periods indicates a shift from observational to more applied research. Consider the word fragments "descri" (describe, description, descriptive, undescribed) and "observ" (observe, observed, observational). They collectively occur 29 (1868-1873), 18 (1919-1923), eight (1969-1973), and 18 (2012-2016) times. Conversely, the word fragments "control" (controlled, controlling) and pest (pests, pestiferous) collectively occur zero (1868-1873), six (19191923), 43 (1969-1973), and 24 (2012-2016) times. The first occurrence of new words or acronyms in titles over time provide reminders of scientific progress; e.g., "synthetic" (Roark 1938), "DDT" (Twinn 1944), "insecticide resistance" (Bartlett 1952), "plastic" (Hocking 1953), "radioactive" (Sullivan 1953), "molecular" (Stavrakis and Wright 1974), "DNA" (Langor and Sperling 1995; Pfeifer et al. 1995; Sperling and Hickey 1995), and "genetically-modified" (Bourassa et al. 2010).

\section{Information loss and degradation}

Detailed examination of the archives also revealed unexpected examples of information modification, loss, and degradation. Our search to find the first figure published in the journal identified two versions of an article published by Saunders (1868). One version digitally archived by Canadiana (http://eco.canadiana.ca/view/oocihm.8_05087_4/2? $\mathrm{r}=0 \& \mathrm{~s}=1$ ) includes a drawing of a butterfly and a sentence at the end of the first paragraph that are absent from a second version digitally archived on TCE's website. A print copy of the article in the Agriculture and Agri-Food Canada library in 
Table 2. In descending alphabetical order, the 50 most common words in text files used to generate word clouds for each of four, five-year time periods (Fig. 3).

\begin{tabular}{|c|c|c|c|}
\hline $\begin{array}{l}\text { Volumes 1-5 } \\
(1868-1873)\end{array}$ & $\begin{array}{l}\text { Volumes 51-55 } \\
(1919-1923)\end{array}$ & $\begin{array}{l}\text { Volumes 101-105 } \\
(1969-1973)\end{array}$ & $\begin{array}{l}\text { Volumes 144-148 } \\
(2012-2016)\end{array}$ \\
\hline NOTES (82) & NEW (157) & NEW (158) & COLEOPTERA (91) \\
\hline MISCELLANEOUS (40) & NOTES (91) & SPECIES (156) & DIPTERA (66) \\
\hline INSECTS (37) & SPECIES (85) & LEPIDOPTERA (147) & SPECIES (64) \\
\hline ENTOMOLOGICAL (31) & DIPTERA (76) & COLEOPTERA (134) & CANADA (61) \\
\hline LARVAE (27) & ENTOMOLOGY (51) & DIPTERA (133) & HYMENOPTERA (59) \\
\hline AMERICA (25) & PRACTICAL (48) & HYMENOPTERA (118) & LEPIDOPTERA (42) \\
\hline ADVERTISEMENTS (23) & POPULAR (48) & EFFECTS (65) & NEW (42) \\
\hline NORTHERN (23) & GENUS (45) & GENUS (58) & BEETLES (37) \\
\hline BRITISH (22) & COLEOPTERA (40) & HOMOPTERA (57) & AMERICA (30) \\
\hline PARTS (22) & CANADIAN (37) & INSECTS (53) & NORTH (24) \\
\hline NEW (22) & LEPIDOPTERA (33) & SCOLYTIDAE (52) & CURCULIONIDAE (23) \\
\hline DESCRIPTIONS (20) & NORTH (28) & NOTES (51) & EFFECTS (22) \\
\hline MICROLEPIDOPTERA (19) & HEMIPTERA (27) & BEETLES (46) & INSECTS (21) \\
\hline LEPIDOPTERA (17) & INSECTS (26) & PINE (45) & HEMIPTERA (19) \\
\hline LIST (17) & AMERICAN (23) & ONTARIO (42) & HOST (19) \\
\hline SOCIETY (15) & BRITISH (23) & NORTH (41) & BUPRESTIDAE (18) \\
\hline CANADIAN (14) & ENTOMOLOGICAL (21) & LARVAE (40) & FOREST (17) \\
\hline RECEIVED (13) & HYMENOPTERA (16) & APHIDIDAE (38) & POPULATIONS (17) \\
\hline BOOKS (13) & CORRECTIONS (16) & BIOLOGY (38) & BORER (16) \\
\hline COLEOPTERA (12) & DESCRIPTIONS (15) & PARASITES (36) & GENUS (16) \\
\hline CORRESPONDENTS (11) & COLUMBIA (15) & TORTRICIDAE (34) & $\mathrm{ASH}(16)$ \\
\hline BUTTERFLIES (11) & TWO (15) & APHID (34) & HISTORY (14) \\
\hline SPECIES (11) & REVISION (14) & TWO (33) & CECIDOMYIIDAE (13) \\
\hline ONTARIO (10) & CANADA (12) & EGGS (31) & DIVERSITY (13) \\
\hline AMERICAN (9) & CRANEFLIES (12) & MOTH (31) & CANADIAN (13) \\
\hline COMMON (9) & SYRPHIDAE (12) & DESCRIPTIONS (30) & REVIEWS (13) \\
\hline NORTH (9) & AMERICA (12) & DEVELOPMENT (30) & EMERALD (13) \\
\hline MEETINGS (8) & SOCIETY (12) & STUDIES (30) & TWO (13) \\
\hline BRANCH (8) & ONTARIO (12) & CHIRONOMIDAE (29) & TORTRICIDAE (12) \\
\hline LONDON (7) & TIPULIDAE (11) & SPRUCE (29) & ASSOCIATED (12) \\
\hline CANADA (7) & STUDIES (11) & CONTROL (28) & REVISIONS (12) \\
\hline HYMENOPTERA (5) & UNDESCRIBED (10) & STAGES (27) & CONTROL (12) \\
\hline ENTOMOLOGY (5) & HETEROPTERA (10) & CHORISTONEURA (26) & STATES (12) \\
\hline CURRANT (5) & COLLECTION (10) & BEHAVIOR (26) & UNITED (12) \\
\hline ANNUAL (5) & MEETINGS (10) & AMERICA (26) & PINE (12) \\
\hline HINTS (5) & NEARCTIC (10) & CANADA (26) & PARASITOID (11) \\
\hline WORKS (5) & WESTERN (10) & POPULATIONS (24) & PHEROMONE (11) \\
\hline FOUND (5) & FLORIDA (10) & PYRALIDAE (24) & SEASONAL (11) \\
\hline LEPIDOPTEROUS (4) & GENERA (10) & HEMIPTERA (24) & CERAMBYCIDAE (10) \\
\hline NOMENCLATURE (4) & LIFE (10) & ACARINA (24) & BRACONIDAE (10) \\
\hline COLORADO (4) & ALBERTA (9) & BUDWORM (24) & SPRUCE (10) \\
\hline HESPERIA (4) & ANNUAL (9) & LIFE (24) & PESTS (10) \\
\hline ALABAMA (4) & GROUP (9) & NOCTUIDAE (23) & USING (10) \\
\hline TAKEN (4) & BEES (9) & REVIEWS (23) & BASED (10) \\
\hline EGGS (4) & COCCIDAE (8) & FUMIFERANA (22) & SEX (10) \\
\hline ENTOMOLOGIST (3) & SOUTHERN (8) & THREE (22) & NOCTUIDAE (9) \\
\hline LIMENITIS (3) & COLLECT (8) & HOST (22) & NEARCTIC (9) \\
\hline GLEANINGS (3) & BEETLES (8) & ORTHOPTERA (21) & NATURAL (9) \\
\hline HEMITELES (3) & ODONATA (8) & EUROPEAN (21) & WESTERN (9) \\
\hline TEMPERATE (3) & LARVAE (8) & POPULATION (20) & ONTARIO (9) \\
\hline Total terms -344 & Total terms -940 & Total terms -2500 & Total terms - 1819 \\
\hline Total words - 1043 & Total words -2583 & Total words -8091 & Total words -3979 \\
\hline
\end{tabular}

Note: Values in brackets identify the number of occurrences. Names of insect orders (bold font) were excluded from word lists before generating word clouds. 
Ottawa, Ontario, contains the drawing, but is printed on a different type of paper than other issues with which it is bound in the volume. We speculate that the drawing was mistakenly omitted from the original submission, necessitating a second print run containing the image.

In preliminary efforts to generate the word clouds, we became aware that different databases contain incomplete holdings of the journal archives. Search results of TCE items in SCOPUS (www.scopus.com/freelookup/form/author.uri) mainly return the titles of scientific articles, but not the correspondence type items published in early issues of the journal. For example, a title word search of "advertisement" in the online archive of the journal and Scopus returns 33 and 0 items, respectively. It was for this reason that we used the TCE archive to generate word clouds that best captured the character of the journal over time. We also determined that print copies of volume 42 include a photographic plate of Charles Bethune to mark his second retirement as the Editor of the journal (Lyman 1910), but this photograph is missing from the digital archive of the journal.

We observed several cases of information degradation in digital archives, generated by electronic or human error. The electronic scanning process used to digitise hardcopy documents can misinterpret letters to generate typographical mistakes. Thus, in the title of an article by Quednau (1970), Chrysocharis laricinellae and Agathis pumila appear in SCOPUS as "chrysocharzs larzcznellae" and "agathzs pumzla".

While recognising the immense value of digital archives, our collective observations emphasise that original print copies - or direct digital scans akin to photocopies such as those held at the Biodiversity Heritage Library (Smithsonian Institution) provide the most accurate and complete history of $T C E$. Even in that situation, however, verification of textual data is best obtained by visual inspection.

\section{Bilingualism}

It is unclear to us when TCE adopted an official policy of publishing papers in either French or English. Articles were published in French at least as early as 1953 (Bellemare and Belcourt 1953; Robert 1953). Starting in 1980, submission of abstracts in both French and English was encouraged as part of a general policy to support bilingualism among members of the Entomological Society of Canada (Turnock 1980). In 1981, acceptance in TCE became conditional upon provision of an abstract in both languages. In 2014, this policy was dropped as an official requirement due to delays in the publication process associated with obtaining translations (Anonymous 2014). Authors are now required to submit an abstract in the language of their manuscript (English or French), but retain the option of submitting abstracts in both languages.

Over the years, the number of papers published in French has averaged about 1\%; e.g., 19691973,11 of 926 items (1.2\%); 2012-2016, four of 341 items $(1.2 \%)$. The corresponding authors for three of the latter four papers are from Algeria (Chafaa et al. 2013), Belgium (Bawin et al. 2014), and France (Hamdi and Bonato 2013). The fourth paper (Langor and Alfaro 2016b), from Canada, is not a scientific article, but rather a French translation of an introduction in English (Langor and Alfaro 2016a) prefacing the contents of a Supplemental Issue. This pattern reflects English as the primary language of science communication by the international community. It also shows that the bilingual policy of the journal is rarely used and then, mainly by non-Canadian authors.

\section{Changing times and technologies}

The past 25 years have seen fundamental changes in the submission, publication, and dissemination processes of the journal. For most of the history of the journal, manuscripts were sent to the Editor as printed documents and forwarded to reviewers, who would return their comments and hardcopy-edited documents to the Editor, to thence be returned to the authors - with all communication by surface mail. This process would take months - longer, if revisions were required. In 1994, implementation of e-mail facilitated communication among the editorial board (Kevan 1994) and the journal adopted a policy of also accepting submissions on electronic diskette (Gerber 1994). In 2006, the journal began accepting submissions only in electronic format (Quiring 2006) and began implementation of an entirely web-based submission system (Bennett 2006). Now, all submissions are handled via ScholarOne Manuscripts, a web-based peerreview management system. 
Fig. 3. Word clouds illustrating topics and taxa during four time intervals in the history of The Canadian Entomologist.

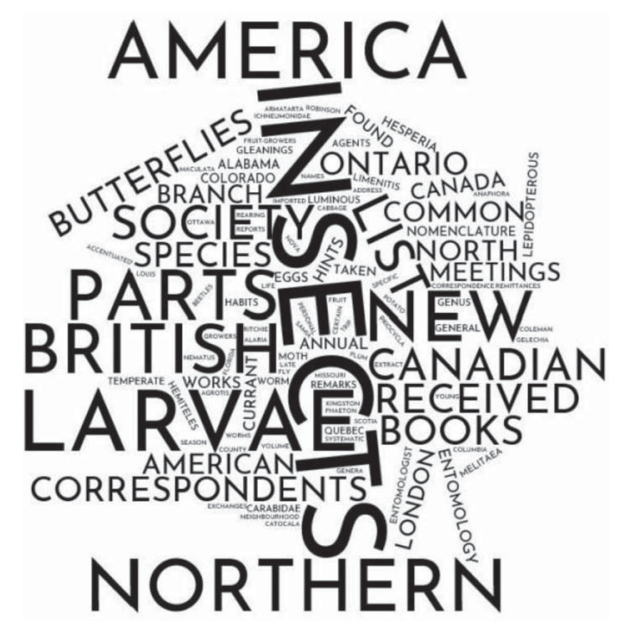

1868-1873

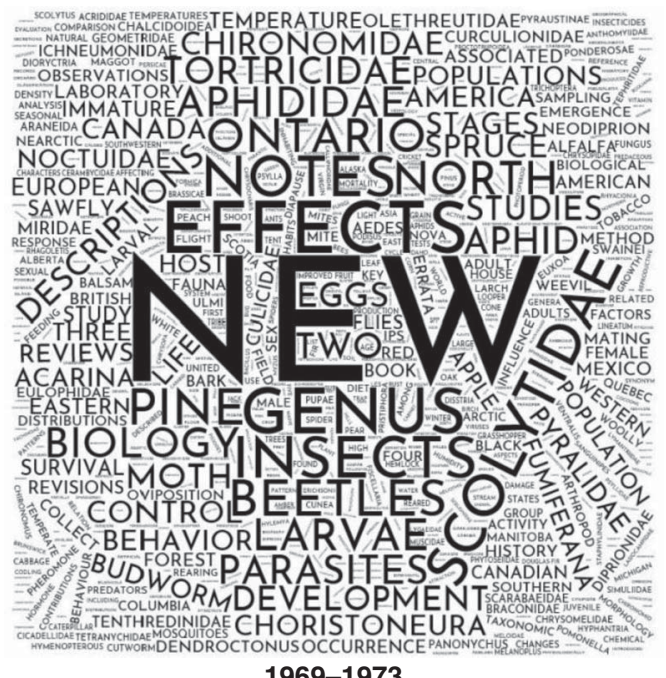

1969-1973

With these most recent changes, time from submission to final decision can be less than a day. Each submission is given a preliminary assessment to determine whether it meets the mandate of the journal, whether the writing quality is sufficiently clear to allow for a critical scientific review, to ensure that all figures and tables are included, and to assess potential plagiarism. About one-third of submissions are rejected at this stage with the authors being notified within a few days. A further one-third of submissions are rejected after a full review. Time from submission to final decision for all manuscripts has averaged 43 days in recent years

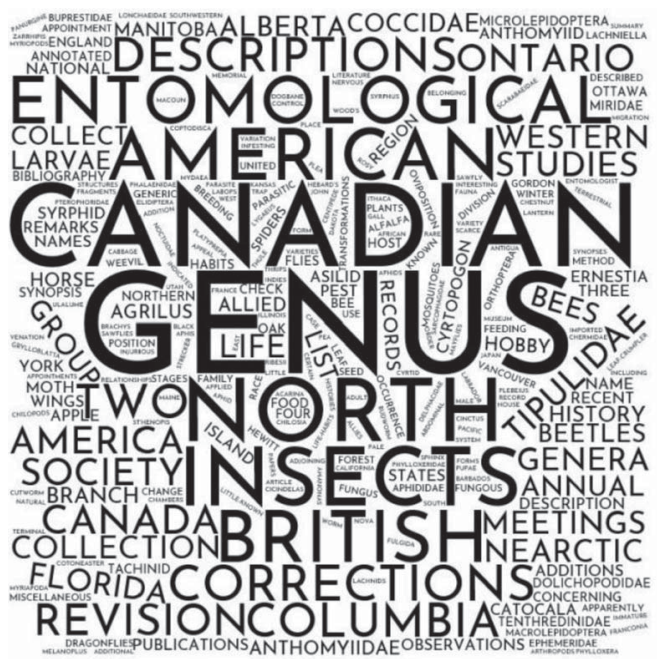

1919-1923

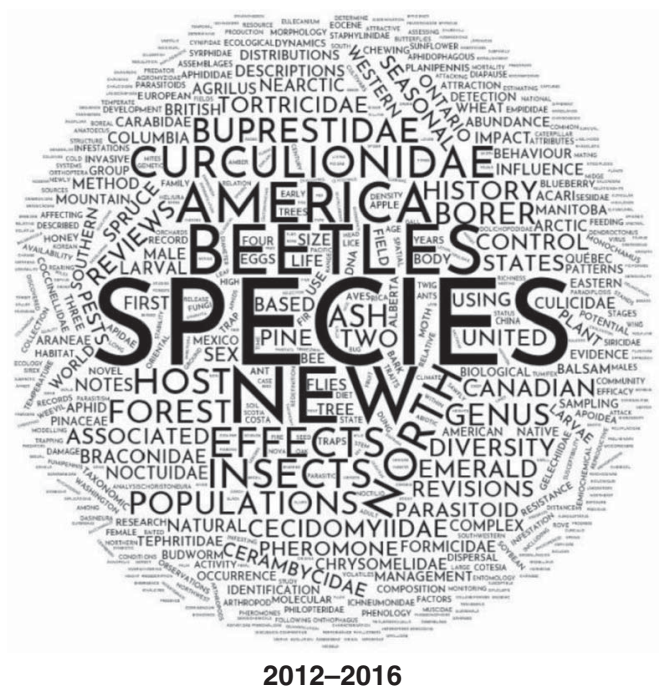

with a rejection rate of $60-70 \%$ in each of the past five years. We try to minimise turn-around times, but often these are affected by events beyond our control. In one case, 24 invitation letters were sent to reviewers who all declined. The manuscript was subsequently unsubmitted by the editorial office and returned to the authors without review.

With the transition in 2012 to Cambridge University Press as the not-for-profit publisher of the journal, authors no longer pay page charges for text or figures, regardless of whether they are in colour or in grey scale. The journal also now allows for articles to be published with 
Supplementary Material - i.e., online-only files (tables, figures, videos, data sets, etc.) made freely available to all and electronically linked to the published paper. The version of record for each accepted article appears online as FirstView in advance of being assigned to a volume and issue, which makes the article more quickly available to readers. In 2014, the journal adopted a hybrid Gold Open Access model to give authors the option of paying a one-time open access fee to make their articles freely accessible online (and subject to one of three different Creative Commons Licences). Access to journal articles beyond the open access options requires an institutional or personal subscription. Personal subscriptions are included with membership in the Entomological Society of Canada.

Revenue from subscriptions or open access fees is split between the Society and Cambridge University Press. Revenues returned to the Society support the position of the Assistant Editor of the journal, who provides scientific and copy-editing services for accepted manuscripts to ensure that published papers are of a uniform high quality. Revenue to the Society also subsidises the cost of student memberships and supports student scholarships and travel awards, the organisation of annual meetings, and entomological events hosted by the regional entomological societies in Canada. Revenue returned to the publisher pays for investment in staff training and salaries, and ensures that key activities across editorial, production, marketing, and platform development (Cambridge owns and develops its own crossbooks and journals platform, Cambridge Core) remain at the forefront of the latest and best practice in the journals publishing industry. One such activity has been the development of Author Hub, which provides guidance to authors on how they can increase and monitor the readership of their published articles (www.cambridge.org/ca/ academic/authors/author-hub).

\section{The Canadian Entomologist today}

Rapid technological advances have led to an upheaval in journal publication, and a bewildering array of online journals, publication options, and considerations that many authors find confusing. The editorial board tries to stay informed of these developments and modifies journal policy accordingly; e.g., see Floate et al. (2013). Adherence to the mandate of TCE also has served us well. The journal publishes on all facets of entomology, but "(m)anuscripts must contain significant new findings of fundamental and (or) general entomological interest. Low priority is given to confirmatory studies, investigations of local interest, techniques (unless of broad application), range extensions, new records, and non-replicated experiments. Single species descriptions, without significant value-added components (e.g., richly illustrated key, phylogenetic analyses), will not be considered". (www. cambridge.org/core/journals/canadian-entomologist/ information/instructions-contributors).

These efforts seem to be working. Its 150 years of continuous publication establishes TCE as one of the oldest entomological journals in the world. It attracts an increasing number of submissions that have allowed us to expand our page content by $25 \%$ since 2012 . And although its name implies a national focus, the journal is international in scope - receiving submissions from an average of 31 countries in each of the past three years, totalling 47 countries since January 2015. Accepted articles are published without cost to the authors, unless they opt to pay a Gold Open Access fee. An in-house Assistant Editor ensures the quality of published articles that are available via the internet and hardcopy distribution in 55 countries. The impact factor of the journal, a metric frequently used by authors and academic institutions as a measure of journal quality, also has increased in each of the past three years. We note this with some reservation, however, given that the European Association of Science Editors recommends that impact factor specifically not be used as a surrogate for research quality (European Association of Science Editors 2007). Of greater significance, we think, is the current ranking of the journal as 38th out of 91 journals in the "Entomology" category; an increase of 23 positions since 2013.

We think C.J.S. Bethune, the first Editor-inChief, would agree that the journal has met and indeed surpassed his wish that the journal "will by and by grow and increase, and acquire goodly dimensions, and become a handsome and valuable exponent of the progress of the Entomological Science in this Dominion" (Bethune 1868). Its success and growing contributions to a 
now global community of entomologists reflects the collective efforts of authors, reviewers and the editorial board in a partnership that has comprised thousands of individuals spanning 150 years. If they could, I'm sure they would join us in congratulating $T C E$ on this, its sesquicentennial anniversary.

\section{Acknowledgements}

The authors thank H. Catton, D. Edwards, and C. Gillott for their comments on an earlier version of this document. For help extracting information from $T C E$ archives, the authors thank K. Mah. They thank C. Scott for scanning back issues of Bulletin of the Entomological Society of Canada, which are now posted on the website of the Entomological Society of Canada for easy access. They thank the past and present members of the Entomological Society of Canada Heritage Committee who compiled the Cumulative Index of Biographies of Entomologists in Canadian Publications (http://esc-sec.ca/wp/ wp-content/uploads/2017/06/Cumulative-Indexof-Biographies-Final170510.pdf), which greatly facilitated the writing of this article. This is Lethbridge Research and Development Centre publication number 38717087.

\section{Supplementary material}

To view supplementary material for this article, please visit https://doi.org/10.1017/tce.2017.64

\section{References}

Anonymous. 1871. Chicago fire - appeal to entomologists. The Canadian Entomologist, 3: 171-171.

Anonymous. 1922. An appeal for aid. The Canadian Entomologist, 54: 72-72.

Anonymous. 1973. Thank you Pat. Bulletin of the Entomological Society of Canada, 5: 35 .

Anonymous. 1974. Vic Vickery. Bulletin of the Entomological Society of Canada, 6: 127.

Anonymous. 1975. Entomologists among 19 women honored. Bulletin of the Entomological Society of Canada, 7: 60.

Anonymous. 1982. Eugene Gordon Munroe, Gold Medal recipient. Bulletin of the Entomological Society of Canada, 14: 70-72.

Anonymous. 1987. Honorary Members: Eugene Gordon Munroe. Bulletin of the Entomological Society of Canada, 19: 90-91.

Anonymous. 1988. Membres honoraires 1987: Vernon Randolph Vickery. Bulletin of the Entomological Society of Canada, 20: 47-48.
Anonymous. 1993. Entomological journalism wins bronze award. Bulletin of the Entomological Society of Canada, 25: 18.

Anonymous. 2001. Entomological Society of Canada C. Gordon Hewitt Award for outstanding achievement Canadian Entomology 2000 presented-to Kevin D. Floate at Montreal, Quebec, December 3, 2000. Bulletin of the Entomological Society of Canada, 33: 42-44.

Anonymous. 2005. Gold Medal Award - Peter G. Kevan. Bulletin of the Entomological Society of Canada, 37: 198-199.

Anonymous. 2006a. C. Gordon Hewitt Award Chris Buddle. Bulletin of the Entomological Society of Canada, 38: 139-140.

Anonymous. 2006b. Gold Medal Award - Richard A. Ring. Bulletin of the Entomological Society of Canada, 38: 136-138.

Anonymous. 2006c. People in the news - CONGRATULATIONS to Chris Buddle who was elected Director-at-Large. Bulletin of the Entomological Society of Canada, 38: 119-120.

Anonymous. 2010. C. Gordon Hewitt Award Dezene Huber. Bulletin of the Entomological Society of Canada, 42: 161-163.

Anonymous. 2012. Fellows of the Entomological Society of Canada, 2012 - Dr Robb Bennett. Bulletin of the Entomological Society of Canada, 44: $120-121$.

Anonymous. 2014. Highlights from the Board of Directors Meetings in Saskatoon. Bulletin of the Entomological Society of Canada, 46: 216-220.

Arntfield, P. 2011. In memory: Dr Vernon Randolph Vickery (1921-2011). Bulletin of the Entomological Society of Canada, 43: 210-211.

Bartlett, B.R. 1952. A study of insecticide resistance in strains of Drosophila melanogaster Meig. The Canadian Entomologist, 84: 189-205.

Bawin, T., Seye, F., Boukraa, S., Zimmer, J.Y., Delvigne, F., and Francis, F. 2014. La lutte contre les moustiques (Diptera: Culicidae): diversité des approches et application du contrôle biologique. The Canadian Entomologist, 147: 476-500.

Becker, E.C. 1977. Williamson James Brown. Bulletin of the Entomological Society of Canada, 9: 100-101.

Becker, E.C. 2001. Pat Pielou (1915-2000). Bulletin of the Entomological Society of Canada, 33: 35.

Becker, E.C. 2004. Recently deceased - Paul Morrison. Bulletin of the Entomological Society of Canada, 36: 39 .

Bellemare, E.R. and Belcourt, J. 1953. Toxicité pour la Blatte américaine d'un nouvel analogue du DDT: 1,1,1-trichloro-2,2-bis-(p-cyanophényl)-éthane. The Canadian Entomologist, 85: 449-453.

Bennett, R. 2006. Greetings from new Editor-in-Chief of The Canadian Entomologist. Bulletin of the Entomological Society of Canada, 38: 143.

Bethune, C.J.S. 1868. Introductory. The Canadian Entomologist, 1: 1-2.

Bethune, C.J.S. 1886. Editorial. The Canadian Entomologist, 18: 181-183. 
Bourassa, S., Cárcamo, H.A., Spence, J.R., Blackshaw, R.E., and Floate, K. 2010. Effects of crop rotation and genetically modified herbicide-tolerant corn on ground beetle diversity, community structure, and activity density. The Canadian Entomologist, 142: 143-159.

Chafaa, S., Biche, M., Chenchouni, H., Sellami, M., and Sibachir, A. 2013. Cycle biologique de Parlatoria oleae (Hemiptera : Diaspididae) inféodée aux oliveraies dans une région aride. The Canadian Entomologist, 145: 398-405.

Chant, D.A. 1967. Harry Scott Smith Award: The Department of Biological Control, University of California. The Canadian Entomologist, 99: 779-779.

Danks, H.V. 1994. Membership trends in the Entomological Society of Canada. Bulletin of the Entomological Society of Canada, 26: 101-113.

Erwin, T.L. 1994. Arboreal beetles of tropical forests: the Xystosomi group, subtribe Xystosomina (Coleoptera: Carabidae: Bembidiini). Part I. Character analysis, taxonomy, and distribution. The Canadian Entomologist, 126: 549-666.

European Association of Science Editors. 2007. EASE statement on inappropriate use of impact factors [online]. Available from www.ease.org.uk/sites/ default/files/ease_statement_ifs_final.pdf [accessed 6 November 2017].

Floate, K.D., Hoover, S., and Cutler, C. 2013. Open access, predatory publishers, The Canadian Entomologist, and you. Bulletin of the Entomological Society of Canada, 45: 131-137.

Freeman, T.N. 1962. James Halliday McDunnough, 1877-1962. The Canadian Entomologist, 94: 10941102.

Gerber, G.H. 1994. President's address. Bulletin of the Entomological Society of Canada, 26: $138-140$.

Gibson, A. 1921. Retirement of Dr. E.M. Walker as Editor. The Canadian Entomologist, 53: 25-25.

Gillott, C. 2008. In memory: Alwyn Bradley Ewen 1932-2008. Bulletin of the Entomological Society of Canada, 40: 194-196.

Gillott, C. 2013a. Part 1: Charles J.S. Bethune (18381932): co-founder of the ESC. Bulletin of the Entomological Society of Canada, 45: 22-24.

Gillott, C. 2013b. Part III. William Saunders (1836-1914): co-founder of the ESC and first Director of the Dominion Experimental Farms. Bulletin of the Entomological Society of Canada, 45: $127-130$.

Hamdi, F. and Bonato, O. 2013. Relation entre sources trophiques et capacité de survie chez Macrolophus pygmaeus (Hemiptera: Miridae). The Canadian Entomologist, 146: 285-290.

Hocking, B. 1953. Plastic embedding of insects - a simplified technique. The Canadian Entomologist, 85: 14-18.

Kevan, P. 1994. Report of Scientific Editor, The Canadian Entomologist. Bulletin of the Entomological Society of Canada, 26: 157-158.
Langor, D.W. and Alfaro, R.I. 2016a. Forest entomology in Canada: celebrating a century of science excellence. The Canadian Entomologist, 148 (Supplement 1): S1-S3.

Langor, D.W. and Alfaro, R.I. 2016b. Entomologie forestière au Canada: célébrer un siècle d' excellence scientifique. The Canadian Entomologist, 148(Supplement 1): S4-S6.

Langor, D.W. and Sperling, F.A.H. 1995. Mitochondrial DNA variation and identification of bark weevils in the Pissodes strobi species group in western Canada (Coleoptera: Curculionidae). The Canadian Entomologist, 127: 895-911.

Lyman, H.H. 1910. The Rev. Charles James Stewart Bethune, M.A., D.C.I,., F.R.S.C. The Canadian Entomologist, 42: 2-3.

Morris, R.F. 1984. Publications: Stephen M. Smith appointed Scientific Editor. Bulletin of the Entomological Society of Canada, 16: 21.

Pfeifer, T.A., Humble, L.M., Ring, M., and Grigliatti, T.A. 1995. Characterization of gypsy moth populations and related species using a nuclear DNA marker. The Canadian Entomologist, 127: 49-58.

Quednau, F.W. 1970. Competition and co-operation between Chrysocharis laricinellae and Agathis pumila on larch casebearer in Quebec. The Canadian Entomologist, 102: 602-612.

Quiring, D. 2006. Up front. Bulletin of the Entomological Society of Canada, 38: 1-2.

Ring, R. 2007. Gold medal address. Bulletin of the Entomological Society of Canada, 39: 58-63.

Roark, R.C. 1938. Synthetic organic compounds used as insecticides. The Canadian Entomologist, 70: 248-253.

Robert, F.A. 1953. Les Odonates du Parc du Mont Tremblant. The Canadian Entomologist, 85: 316-339.

Ross, W.A. 1959. William Robin Thompson. The Canadian Entomologist, 91: 3-4.

Saunders, W. 1868. Entomological notes. Paper No. II. The Canadian Entomologist, 1: 25-27.

Sharkey, M.J. 1992. In memory, Bill Mason (19211991). Bulletin of the Entomological Society of Canada, 24: 82-84.

Solis, M.A. 2008. Eugene G. Munroe, 'The Lepidopterist': 1919-2008. Bulletin of the Entomological Society of Canada, 40: 139-143.

Sperling, F.A.H. and Hickey, D.A. 1995. Amplified mitochondrial DNA as a diagnostic marker for species of conifer-feeding Choristoneura (Lepidoptera: Tortricidae). The Canadian Entomologist, 127: 277-288.

Stavrakis, G.N. and Wright, R.H. 1974. Molecular vibration and insect attraction: Dacus olea (Diptera: Tephritidae). The Canadian Entomologist, 106: 333-335.

Sullivan, C.R. 1953. Use of radioactive cobalt in tracing the movements of the white-pine weevil, Pissodes strobi Peck. (Coleoptera: Curculionidae). The Canadian Entomologist, 85: 273-276. 
Sweeney, J., Fairchild, W., and Thurston, G. 2011. In memory: Doug Eidt 1928-2011. Bulletin of the Entomological Society of Canada, 43: 158-159.

Thompson, W.R. 1948. Editorial. The Canadian Entomologist, 80: 7-8.
Turnock, W.J. 1980. Report of the ESC President (Rapport du Président). Bulletin of the Entomological Society of Canada, 12: 60-66.

Twinn, C.R. 1944. A note on DDT, the new synthetic insecticide. The Canadian Entomologist, 76: 87-88. 